\title{
POLITIK HUKUM ISLAM KULTURAL DALAM PERATURAN TENTANG KOPERASI SYARIAH DI INDONESIA
}

\author{
Nurjamil $^{1}$, Siti Nurhayati ${ }^{2}$ \\ ${ }^{12}$ Institut Koperasi Indonesia (Ikopin) \\ J1. Raya Bandung-Sumedang km 20,5 Sumedang-Jawa Barat, Indonesia 40600 \\ kankjameel@gmail.com
}

\begin{abstract}
Abstrak
Penelitian ini dilakukan untuk mengelaborasi ajaran Islam kulutral dan pengaruhnya dalam membentuk corak politik hukum Islam di Indonesia serta menentukan arah kebijakan politik hukum Islam di Indonesia dihubungkan dengan diberlakukannya Peraturan Perundang-undangan tentang Koperasi Syariah. Penelitian yang dilakukan merupakan penelitian deskriptif analitis dengan pendekatan yuridis normatif. Data diperoleh dari penelitian kepustakaan (library research) selanjutnya dianalisis secara kualitatif dan disimpulkan bahwa ajaran Islam kulutral mempunyai pengaruh yang sangat besar dalam memberi bentuk corak politik hukum Islam di Indonesia yang bersifat heterogen akan tetapi ajaran Islam kultural tidak terlihat begitu kental dalam Undang-Undang Koperasi, justru nilai-nilai Islam diterapkan dalam peraturan-peraturan yang sifatnya lebih rendah dan teknis, yakni peraturan menteri dan fatwa Dewan Syariah NasionalMUI.
\end{abstract}

Kata Kunci: Ajaran Islam Kultural, Koperasi Syariah, Fatwa Dewan Syariah Nasional Majelis Ulama Indonesia

\begin{abstract}
This research was conducted to elaborate the teachings of culutral Islam and its influence in forming the Islamic legal political in Indonesia as well as determining the direction of Islamic legal political policies in Indonesia associated with the enactment of legislation concerning Sharia Cooperatives. The research conducted is an analytical descriptive study with a normative juridical approach. Data obtained from library research is analyzed qualitatively and finally concluded that the teachings of culutral Islam have a very large influence in giving a heterogeneous form of Islamic legal politics in Indonesia but the teachings of cultural Islam did not look so thick in the Law of Cooperatives, in fact, Islamic values are applied in lower and technical regulations, namely ministerial regulations and fatwa of The National Sharia Council of the Indonesian ulama assembly
\end{abstract}

Keywords: Teachings of Cultural Islam, Sharia Cooperative, Fatwa of The National Sharia Council of the Indonesian ulama assembly

I. PENDAHULUAN

Islam merupakan agama yang

memiliki penganut mayoritas di

EISSN: 2540-8402 | ISSN: 2540-8399
Indonesia merupakan sebuah realita.

Tentu saja hal tersebut tidak dapat terjadi seketika, akan tetapi disinyalir 
ada beberapa penyebab yang melatarbelakanginya. Salah satunya adalah adanya akulturasi budaya lokal Indonesia yang kental dengan adat ketimuran dengan budaya Islam, yang boleh jadi dianggap memiliki corak atau bahkan konsep yang tidak jauh berbeda, paling tidak dalam esensinya (Amir Syarifuddin:2005).

\section{Dikarenakan karakternya} yang fleksibel, dalam tataran praktik, tidak dapat dipungkiri apabila kemudian muncul dua aliran besar mengenai konsep Islam itu sendiri, termasuk di dalamnya pemkiran mengenai penerapan hukum Islam. Pertama yaitu pandangan yang tekstual yang mengutamakan simbolik formal. Islam menurut pandangan ini tidak cukup dilaksanakan oleh individu sebagai ajaran agama, akan tetapi harus menjadi aturan resmi bahkan jika perlu Islam menjadi simbol dan dasar negara. Dan kedua, golongan yang berpaham konstekstual atau dikeal dengan Islam kultural, yang menginginkan hukum Islam berlaku tetapi tidak mengutamakan simbol- simbol struktural. Menurut pandangan ini, yang paling penting adalah sesensi dari ajaran Islam itu sendiri yang mewarnai konsep sebuah aturan, tanpa harus menyertakan label Islam di luarnya (Amir Syarifuddin:2005).

Dalam tataran sistem hukum nasional yang menggunakan konsep mix system, artinya percampuran antara hukum aliran Eropa Kontinental (Civil Law), hukum adat dan hukum Islam (Huala Adolf:2006), maka implementasi konsep-konsep Islam dalam sebuah peraturan yang baku, mengikat dan memiliki daya paksa, yang diwujudkan dalam bentuk sebuah peraturan perundang-undangan, seharusnya tidak menemui kendala, alih-alih diyakini sebagai unsur pembentuk hukum yang mewarnai hukum positif di Indonesia, baik dari sisi materi, budaya maupun struktur hukumnya (Moch. Mahfud MD:2010).

Sekali lagi, Indonesia memiliki keunikan tersendiri, karena yang menjadi sumber dalam 
pembentukan hukum, dalam hal ini lebih ditekankan dalam arti undangundang, adalah percampuran antara hukum adat lokal masyarakat Indonesia, hukum Islam dan hukum peninggalan kolonial Belanda. Artinya secara sadar, materi hukum Islam pada dasarnya diakui dan berlaku bagi penduduk yang beragama Islam, bahkan sejak penjajahan kolonial Belanda (Amir Syarifuddin:2005).

Sebagai penduduk mayoritas, tentunya umat Islam memiliki kepentingan yang besar, agar konsep hukum Islam dapat menjadi aturan yang mengikat dan kalau perlu berbentuk sebuah undang-undang. Untuk Indonesia yang penduduknya plural, perjuangan hukum Islam lebih dianjurkan untuk mengikuti pola kultural dan mengesampingkan gerakan simbolik-formal. Yang paling perlu diperjuangkan adalah nilai-nilai substantif ajaran Islam agar dapat mengakar kuat dan bahkan menjadi unsur yang mewarnai materi sebuah peraturan perundang-undangan. Salah satu peraturan perundang-undangan yang merupakan wujud aspirasi penerapan prinsip-prinsip syariah dalam EISSN: 2540-8402 | ISSN: 2540-8399 peraturan perundang-undangan dan dianggap sebagai produk dari perjuangan politik hukum Islam kultural adalah diberlakukannya peraturan perundang-undangan mengenai koperasi syariah. Koperasi syariah merupakan lembaga keuangan mikro yang didirikan untuk meningkatkan kesejahteraan para anggotanya melalui produkproduk pembiayaan yang ditawarkannya. Berdirinya lembaga koperasi tidak didasarkan pada hukum-hukum Islam, namun koperasi mampu menjalankan operasional yang sesuai dengan prinsip Islam yaitu menggunakan prinsip akad syirkah (Amwaluna: Jurnal Ekonomi dan Keuangan Syariah Vol. 1 No.2 (Juli, 2017)

Dari uraian di atas, kemudian yang menjadi pertanyaan besar bagi peneliti adalah mengenai pengaruh hukum Islam kultural tersebut terhadap arah kebijakan politik hukum Islam di Indonesia sendiri khususnya mengenai koperasi yang merupakan konsep ekonomi khas Indonesia dengan demokrasi ekonominya sekaligus konsep syariah yang sudah memiliki pasar tersendiri seiring dengan 
berkembangnya tingkat pemahaman dan pengamalan nilai-nilai masyarakat Indonesia terutama pada dua dekade terakhir bersamaan dengan lahirnya perbankan syariah. Sepanjang pengetahuan peneliti terdapat penelitian terdahulu yang telah dibuat oleh Mardani dengan judul Hukum Islam dalam Sistem Hukum Nasional, dimuat dalam Jurnal Hukum dan Pembangunan, tahun ke 38, No. 2, April-Juni 2008, tetapi tidak secara khusus membahas mengenai politik hukum islam kultural dan kaitannya dengaa peraturan mengenai koerasi syariah. Dalam menjawab pertanyaan tersebut dilakukan penelitian berupa penelitian yang bersifat deskriptif analitis dengan pendekatan yuridis normatif. Data diperoleh dari penelitian kepustakaan (library research) dan selanjutnya data yang diperoleh dianalisis secara kualitatif.

II. PEMBAHASAN

A. Landasan Teori
1. Hubungan Islam dan Politik; Sebuah Diskusi Tanpa Akhir

Islam dan politik merupakan dua tema yang tidak pernah using untuk dijadikan bahan diskusi atau bahkan perdebatan. Bahkan dalamperjalananannya terdapat pandangan bahwa Islam hanya merupakan hubungan antara manusia dengan Tuhannya, sehingga urusan duniawi termasuk politik di dalamnya merupakan urusan yang terpisah dari agama. Golongan ini mengatakan bahwa "innad diina syai-un wasiyasatu syai-un a-khar". Pandangan lain mengatakan bahwa Islam mempunyai konsep dan aturan yang lengkap, bukan hanya mengenai hubungan antara manusia dengan Tuhannya tapi juga urusan manusia dengan sesamanya, termasuk di dalamnya aturan berpolitik (Teungku Muhammad Hasbi Ash Shiddieqy:2002).

Menurut

Teungku Muhammad Hasbi Ash Shiddieqy bahwa tata aturan Islam sesungguhnya merupakan tata aturan 
yang bersipat politik dan bersipat agama. Sebagai rujukan beliau juga gambarkan mengenai sejarah pembentukan negara Islam di Madinah oleh Nabi Muhammad saw dan para sahabatnya merupakan tata aturan yang sangat kental dengan politik, yang dikenal dengan konsep syura (Teungku Muhammad Hasbi Ash Shiddieqy:2002).

Sebagai catatan, ternyata sejarah politik Islam di kemudian hari juga sangat dipengaruhi oleh warisan Romawi dan persia. Sebagaimana (Rusjdi Ali Muhammad:2003) mengatakan:"Dari kenyataan sejajarah, masa kira-kira 30 tahun pertama sejarah Islam setelah wafat Nabi Muhammad saw, sejarah Islam tidak mengenal sistem politik dinastik dan sistem kerajaan. Tetapi dalam perkemabangan lebih lanjut, akibat kuatnya pengaruh warisan Romawi dan Persia sejak zaman Khalifah Umayyah (tahun 661749M), maka doktrin politik egaliter tersebut terbenam di bawah pengaruh tersebut".

Meskipun demikian banyak literatur yang berkaitan dengan pemikiran politik tokoh-tokoh menyimpulkan bahwa agama dan negara berhubungan secara komplementer dan integralistik, di mana agama menjadi roh negara. (Usman:2017)

\section{Konsep Islam Tentang Politik dan Hukum}

Secara sederhana gambaran tentang politik atau dalam literatur keislaman sering disebut dengan istilah siyasah syariyyah yang akar katanyaterambil dari kata sasa-yasusu (Abdullah Zawawi:2015) meliputi beberapa hal berikut (Abu Ridha:2004):

a) Siasah Islam menghormati eksistensi kemanusiaan dan akal sehat (dasar-dasar dan prinsipnya sejalan dengan tata alamiah)

b) Siasah Islam merupakan sistem yang mutlak adil, tidak membedakan manusia berdasarkan ras, keturunan, serta harta kekayaan dan beranggapan bahwa semua manusia sama di hadapan hukum (equal before the law) (Rusjdi Ali Muhammad:2003)

c) Siasah Islam konsisten dengan syarat-syarat seorang pemimpin yakni kesatriaan, kemuliaan, keimanan, ketakwaan, 
kebersamaan, kekeluargaan, dan pengalamannya dalam urusan agama dan dunia.

d) Siasah Islam merupakan bagian dari satu sistem yang menyeluruh dan cara hidup yang total (kaafah).

e) Tidak ada tempat bagi pemikiran sekuler yang memisahkan dunia dari agama. Siasah Islam adalah bagian dari agama.

Sementara berkaitan dengan hukum, pandangan umum hukum sering diartikan sebagai kaidah atau norma yang hidup sebagai pedoman pergaulan di dalam masyarakat yang pelaksanaannya dapat dipaksakan dengan sanksi dan diterapkan oleh lembaga yang berwenang sebagai aturan yang mengikat. Artinya kaidah yang belum diterapkan oleh lembaga yang berwenang (seperti parlemen) secara kategoris tidak disebut hukum, meskipun secara harfiah sering disebut hukum.

\section{Menurut}

(Satjipto

Rahardjo:2006) ciri yang menonjol hukum yang "murni", yaitu dibuat secara sengaja oleh suatu badan perlengkapan dalam masyarakat yang khusus ditugasi untuk menjalankan penciptaan dan pembuatan hukum itu. Menurut (Moch. Mahfud MD:2010), Hal yang mendasari pemikiran tentang hukum, adalah adanya aturan main dalam kehidupan bermasyarakat yang menciptakan ketertiban. Dasar pemikiran tersebut digambarkan dalam adagium "ubi societas ibi ius", yang artinya "di mana ada masyarakat di sana ada hukum". Dari adagium tersebut jelas, bahwa hukum hanya ada di tengah-tengah masyarakat, sehingga jika orang hidup sendiri (meskipun tidak mungkin) maka hukum dapat dikatakan tidak ada. Orang menjadi terikat pada hukum karena dia hidup dengan orang lain yang mempunyai kepentingan masing-masing. Dalam menaati hukum, adagium tersebut, ternyata masih memberikan peluang bagi manusia untuk melakukan pelanggaran, apabila merasa hidup sendiri atau merasa perbuatannya tidak diketahui oleh orang lain 
Dalam konsep Islam, hukum itu ada tanpa harus seseorang hidup dengan orang lain. Meskipun seumpamanya orang hidup sendiri, hukum itu ada karena hukum diberlakukan sebagai alat kontrol dan pengatur hidup seseorang sebagai khalifah baik ketika berhubungan dengan manusia lain, maupun hubungannya pribadinya dengan Tuhan. Dengan prinsip seperti itu, ketaatan seseorang dituntut untuk selalu konsisten, kapan dan dimanapun ia berada karena selalu merasa diawasi Tuhan, sekalipun tidak ada orang yang mengetahui.

\section{Antara Islam Struktural dan Islam Kultural; Sebuah Kajian Perbandingan}

Penerapan hukum Islam dengan segala konsepnya yakni penerapan hukum Islam dalam bentuk syari'ah dan fikih. Syariah memiliki sejarah yang singkat, yaitu ketika Nabi memulai dakwahnya di Mekah dan di Madinah, kurang lebih 23 tahun. Sedangkan fikih berkembang sejak masa kenabian sampai sekarang (M. Khoirul Anam:2004). Sejak islam berkuasa dimulai dengan didirikannya negara madinah sampai dengan runtuhnya EISSN: 2540-8402 | ISSN: 2540-8399
Islam setelah perang salib, sampai saat ini telah mengalami pasang surut. Penerapannya di negara-negara tertentu seperti, Brunei Darussalam, Saudi Arabia, Malaysia dan Indonesia telah mengalami banyak perkembangan dan penyesuaian tetapi dengan tetap menjaga esensi syariat itu sendiri dengan dalih maqashidusyariah dan kemaslahatan umat. Hal tersebut dikarenakan sejak awal konsep mengenai politik dan hukum Islam itu sendiri telah berbeda, antara Islam yang tekstual dan kontekstual.

Dilihat dari penerapan hukum Islam, dalam membumikan hukum Islam itu sendiri, tampaknya di Indonesia belakangan semakin mengkrucut menjadi dua gerakan. Yang pertama, gerakan formalstruktural, biasanya disebut Islam politik atau Islam struktural. Gerakan ini memperjuangkan Islam menjadi simbol atau wadah formal dalam organisasi negara, mulai dari bentuk yang paling tinggi, yakni mengubah dasar dan bentuk negara menjadi negara Islam sahingga ajaran diberlakukan dalam bentuk undangundang atau qanun. Yang kedua, gerakan Islam kultural yang 
menyebarkan dan menanamkan nilainilai substantif tanpa melibatkan simbol Islam dan tidak mengharuskan berdirinya negara Islam atau memformalkan hukum Islam melalui kekuasaan negara (Moch. Mahfud MD:2010).

\section{Hukum Islam Dalam}

\section{Lintasan Sejarah Indonesia}

Pada masa penjajahan

Belanda, sesungguhnya hukum Islam sudah berlaku di Indonesia berdasarkan pada dua teori, yakni teori Receptie in Complexu yang dikemukakan oleh Lodewijke Willem Cristian Van den Berg (1845-1927) yang dalam tahun 1884 menulis buku Muhammadan Recht (asas-asas hukum Islam), yang intinya menyatakan bahwa "hukum Islam diperlukan bagi orang-orang Islam Bumi Putra walaupun dengan sedikit penyimpanganpenyimpangan" (Idris

Ramulyo:1997).

Pendapat ini sesuai dengan Reegering Reglement (Stb 1884 No.129 di negeri Belanda jo. Stb 1885 No.2 di Indonesia, terutama diatur dalam pasal 75, pasal 78, jo Pasal 109 RR tersebut). Pasal 75 ayat (3) RR tersebut mengatur : “ apabila terjadi sengketa perdata antara orangorang Indonesia yang beragama Islam oleh Hakim Indonesia haruslah diperlakukan Hukum Islam Gonsdienting Wetten dan kebiasaan mereka" (Idris Ramulyo:1997).

Kemudian terdapat teori receptie yang menentang teori receptie in complexu yang di kemukakan oleh Christian Snouck Hoergronje (1857-1936) yang menyatakan Hukum Islam baru dianggap berlaku sebagai hukum apabila telah memenuhi 2 syarat yaitu : pertama, Norma hukum Islam harus diterima terlebih dahulu oleh hukum kebiasaan (adat masyarakat setempat), kedua, kalaupun sudah diterima oleh hukum adat, norma dan kaidah hukum Islam itu juga tidak boleh bertentangan ataupun tidak boleh telah ditentukan lain oleh ketentuan perundang-undangan Hindia Belanda (Idris Ramulyo:1997). 
Secara tegas sejak berdirinya negara Indonesia dinyatakan bahwa Indoensia adalah negara hukum yang berdasarkan konstitusi UUD 1945. Bukan negara sekuler, bukan pula negara Islam. Sebagai bukti konkrit, dapat dipahami bahwa hukum yang berlaku di Indonesia terdiri tidak terlepas dari tiga sumber hukum utama, yakni; pertama, hukum barat yang merupakan hukum peninggalan penjajahan Belanda yang di berlakukan di Indonesia berdasarkan Pasal II aturan peralihan. Kedua, hukum Islam yang bersumber dari Al-Qur`an dan Al-hadits diberlakukan karena mayoritas rakyat di Indonesia beragama Islam. Ketiga hukum adat, di dalam UUD 1945 negara mengakui dan menghormati kesatuan-kesatuan masyarakat hukum adat beserta hakhak tradisionalnya sepanjang masih hidup dan sesuai dengan perkembangan masyarakat dan prinsip NKRI.

\section{B. Pengaruh Ajaran Islam} Kultural Terhadap Politik Hukum

\section{Islam di Indonesia}

Islam adalah agama yang sangat sempurna dan ajarananya EISSN: 2540-8402 | ISSN: 2540-8399 mencakup semua aspek kehidupan, termasuk di dalamnya politik yang dikenal dengan politik islam dan politik hukum islam yaitu cara menerapkan nilai-nilai hukum Islam dalam sebuah peraturan.

Bagaimana cara untuk membumikan hukum Islam itu sendiri, sebagaimana telah dipaparkan di atas, nampaknya semakin mengkrucut, menjadi dua gerakan, yang boleh dikatakan kedua-duanya mempunyai tujuan yang sama namun menggunakan pendekatan yang berbeda. Yang pertama, gerakan formal-struktural, biasanya disebut Islam politik atau Islam struktural. Gerakan ini memperjuangkan Islam menjadi simbol atau wadah formal dalam organisasi negara, mulai dari bentuk yang paling tinggi, yakni mernjadi negara Islam sampai menjadikan hukum Islam resmi seperti UndangUndang atau Kanun. Yang kedua, gerakan Islam kultural yang menyebarkan dan menanamkan nilainilai substantif tanpa melibatkan simbol Islam dan tidak mengharuskan berdirinya negara Islam atau memformalkan hukum Islam melalui kekuasaan negara. 
Sumber hukum nasional yang terdiri dari tiga komponen, yakni hukum adat, hukum barat dan hukum Islam, menurut (Moch Mahfud MD:2010) sebaiknya ketiga hukum tersebut dipadukan dan tidak perlu diberlakukan masing-masing secara ekslusif, karena masing-masing sumber hukum tersebut memiliki nilai-nilai kebaikan yang berlaku universal. Hukum Islam sendiri, yang dimaksudkan di sini adalah fiqh (hasil ijtihad), sehingga pemberlakuannya dapat disesuaikan dengan kondisi dan keadaan masyarakat tanpa mengubah substansinya. Sebagai contoh, hukum potong tangan bagi pencuri, dalam wacana ijtihad para ahli fiqih, ditafsirkan menjadi potong kesempatan untuk mencuri, sehingga muncullah hukuman kurungan/penjara. Bahkan dalam wacana ilmiah terakhir, konsep potong kesempatan tersebut, menurut Yusril Ihza Mahendra, diartikan sebagai pembuatan kebijakan/perundang-undangan yang tidak memeberikan celah bagi terjadinya korupsi.

Dalam kajian hukum sebagai sebuah sistem, dengan banyaknya undang-undang yang lahir yang diakui sebagai bentuk formalisasi aspirasi ajaran fiqih islam, maka dapat dikatakan ajaran islam kultural memberikan pengaruh yang sangat kuat terhadap pergerakan politik hukum islam di Indonesia.

C. Arah Kebijakan Politik Hukum Islam Indonesia Dalam Peraturan Perundangan Mengenai Koperasi Syariah

Politik sebagaimana yang dimaksud oleh Van Der Tas yaitu beleid (kebijakan) (Hasan Alawi:2005). Apabila dikaitkan dengan politik hukum, peneliti cenderung memahaminya sebagai sebuah bentuk peraturan yang dibuat oleh pemerintah atau lembaga negara yang mempunyai kewenangan dalam membuat peraturan tersebut sebagai sebuah kebijakan yang menentukan arah berkehidupan suatu bangsa. Bentuk nyata yang paling kental 
dengan hal tersebut adalah diundangkannya sebuah peraturan.

Sebagaimana disinggung di awal, bahwa peraturan perundangan perkoperasian dalam hal ini lebih khusus mengenai koperasi syariah, sebagaimana Undang-Undang No 1

Tahun 1974 Tentang Perkawinan, Peraturan Menteri Agama RI No 2 Tahun 1987 Tentang Wali Hakim, Instruksi Presiden No 1 Tahun 1991 Tentang Kompilasi Hukum Islam, Undang-Undang No 38 Tahun 1999 Tentang Pengelolaan Zakat, UndangUndang No 41 Tahun 2004 Tentang Wakaf, dan Undang-Undang No 21 Tahun 2008 Tentang Perbankan Syariah merupakan salah satu produk perundang-undangan yang disinyalir sangat kuat dipengaruhi oleh aspirasi umat Islam di Indonesia, bahkan perjalanan sejarah telah merekam begitu panjang proses awal sampai lahirnya peraturan perundangundangan tersebut.

Ketika politik hukum diartikan sebagai legal policy artinya arah hukum yang akan diberlakukan oleh negara untuk mencapai tujuan negara yang bentuknya dapat berupa pembuatan hukum baru dan penggantian hukum lama (Moch. EISSN: 2540-8402 | ISSN: 2540-8399
Mahfud MD:2010) dalam hal ini berkaitan dengan diberlakukannya peraturan perundangan mengenai koperasi syariah, peneliti melihat bahwa arah kebijakan yang dimaksud adalah mengakomodir aspirasi masyarakat Indonesia yang sudah sangat familiar dengan nilainilai koperasi untuk terus bekerjasama dalam berdemokrasi termasuk dalam ekonomi lebih khusus lagi umat Islam yang kebetulan mayoritas memilih faham madzhab syafi'i dengan realita disepakatinya tiga belas kita fikih rujukan bagi para hakim di pengadilan agama dalam menyelesaikan masalah perkawinan, kewarisan, wakaf, dan bahkan (ekonomi syariah; tambahan peneliti), merupakan kitab-kitab fikih bermadzhab syafi'i (Amir Syarifuddin:2005) menginginkan adanya keajegan nilai-nilai syariah dalam bentuk hukum positif yang memiliki daya paksa dan kepastian secara hukum yang semuanya hanya dapat diwujudkan dalam satu bentuk paraturan perundang-undangan. Harapannya tentu saja agar nilai-nilai Islam yang sudah sejak lama mewarnai cara berhukumnya orang 
Indonesia, kemudian dapat memiliki ketegasan dan pengakuan dari negara. Dengan begitu perjuangan umat Islam, yang dalam porsi tertentu mengharuskan diberlakukannya hukum islam, paling tidak satu demi satu dapat terwujud walaupun dengan tetap memperhatikan konteks keIndonesiaan yang dikenal multi agama, etnik bahasa dan budaya.

Sebelum menguraikan mengenai bentuk konkrit penyerapan nilai-nilai islam dalam peraturan perundangan mengenai koperasi syariah, terlebih dahulu perlu diuraikan mengenai peraturan tentang koperasi secara umum yang meliputi

(http://kementeriankoperasi.com/land asan-hukum-koperasi-syariah/):

\section{Pra kelahiran UU Nomor 25 Tahun 1992 tentang Perkoperasian}

Ada berbagai rujukan yang dijadikan sebagai landasan hukum koperasi syariah pada pereode ini, antara lain:

a) Verordening op de Cooperatieve Verenigingen (Stbl. Nomor 431
Tahun 1915) Merupakan regulasi pertama yang berlaku bagi semua golongan penduduk (Pasal 131 IS) yang ada di Indonesia. Peraturan ini timbul atas adanya kekosongan hukum akan pengaturan koperasi

b) Regeling Inlandsche Cooperatieve Verenigingen (Stbl Nomor. 91Tahun 1927) Pada saat politik balas budi Belanda baru saja didengungkan, perjuangan para nasionalis berhasil dengan keluarnya "Regeling Inlandsche Cooperatieve Verenigingen”. Peraturan Koperasi ini tunduk pada Hukum Adat dan bukan pada BW( Hukum Perdata Belanada).

c)Algemene Regeling op de Cooperatieve Verenigingen (Stb Nomor . 108 Tahun 1933) merupakan perubahan dari Verordening op de Cooperatieve Verenigingen yang berlaku bagi penduduk golongan I, II dan III, namun di sisi lain Regeling Inlandsche Cooperatieve Verenigingen masih diberlakukan untuk Gol. III(pribumi). Pada masa ini, Departemen Ekonomi atas 
anjuran dari Jawatan Koperasi mendirikan gabungan dari pusatpusat koperasi di Hindia Belanda yang dinamakan Moeder Centrale.

d) Regeling Cooperatieve Verenigingen (Stb. Nomor 179 Tahun 1949). Regulasi yang pertama kali dicetuskan sejak kemerdekaan Indonesia ini, muncul karena adanya krisis yang berkepanjangan mulai dari agresi militer Belanda, hingga pemberontakan PKI.

e) Undang-Undang Nomor 79 Tahun 1958 Tentang Perkumpulan Koperasi. Undang undang ini dibuat dengan sangat tergesa-gesa, sehingga tidak membawa banyak perubahan bagi eksistensi kelembagaan koperasi.

f) Peraturan Pemerintah Republik Indonesia Nomor 60 Tahun 1959 tentang Perkembangan Gerakan Koperasi.

g)Instruksi Presiden Republik Indonesia Nomor 2 dan 3 Tahun 1960. Sebagai peraturan pelaksana dari Peraturan Pemerintah, maka dibentuk Badan Penggerak Koperasi sebagai wadah tunggal kerjasama antar jawatan koperasi dan masyarakat
h)UU Nomor 14 tahun 1965 Tentang Pokok-pokok Perkoperasian. Undangundang ini sebagai pengejahwantahan prinsip Nasakom yang mengebiri prinsip koperasi di Indonesia.

a) Undang-Undang RI Nomor 12 tahun 1967 Tentang Pokok-pokok Perkoperasian.

2. Masa berlakunya UU Nomor 25 Tahun 1992 tentang Perkoperasian

Berlakunya Undang-Undang Perkoperasian ternyata belum memberikan angina segar bagi keberadaan koperasi syariah, sehingga untuk mengatasi kekosongan hukum di bidang koperasi berbasis syariah yang sebagian besar merupakan hasil koversi dari BMT, banyak dibuat regulasi setingkat dengan Peraturan pemerintah dan Peraturan Menteri. Beberapa Peraturan Pemerintah dan Peraturan Menteri terkait yang mengatur tentang landasan hukum koperasi syariah saat ini antara lain:

a) Peraturan Pemerintah Republik Indonesia No 9 Tahun 1995 tentang pelaksanaan Usaha Simpan Pinjam oleh Koperasi 
b) Keputusan Menteri Koperasi, Pengusaha Kecil dan Menengah Republik

Indonesia Nomor :
323/BH/KWK-12/V/1999, Tanggal 24 Mei 1999;

c) Keputusan Menteri Negara Koperasi dan UKM Republik Indonesia Nomor 91/Kep/M.KUKM/IX/2004 tanggal 10 September 2004 Tentang Petunjuk

Pelaksanaan Kegiatan Usaha Koperasi Jasa Keuangan Syariah;

d) Peraturan Menteri Negara Koperasi dan Usaha Kecil dan Menengah RI No:35.2/PER/M.KUKM/X/2 007 tentang Pedoman Standar Operasional Manajemen Koperasi Jasa Keuangan Syariah dan Unit Jasa Keuangan Syariah;

e) Peraturan Menteri Negara Koperasi Dan Usaha Kecil Dan Menengah Republik IndonesiaNomor 35.3/Per/M.Kukm/X/2007
Tentang Pedoman Penilaian Kesehatan Koperasi Jasa KeuanganSyariah Dan Unit Jasa Keuangan Syariah Koperasi;

f) Pasal 1320 KUH Perdata tentang Syarat sah perjanjian;

g) Pasal 1243 KUH Perdata tentang penggantian biaya, kerugian dan bunga karena tak dipenuhinya suatu perikatan;

h) Undang - undang Nomor 3 Tahun $2006 \quad$ Tentang Peradilan Agama terkait dengan Penyelesaian sengketa;

i) Undang undang RI Nomor 20 Tahun 2008 tentang Usaha Mikro, Kecil dan Menengah;

j) Fatwa Dewan Syari'ah Nasional Nomor: 02/DSNMUI/ IV/2000 Tentang Tabungan (wa'diah);

k) Fatwa Dewan Syari'ah Nasional Majelis Ulama Indonesia Nomor: 03/DSNMUI/IV/2000, tentang Deposito; 
1) Fatwa Dewan Syari'ah Nasional Majelis Ulama Indonesia No: 04/DSNMUI/IV/2000;

m) Fatwa Dewan Syari'ah Nasional No: 08/DSNMUI/ IV/2000 Tentang Pembiayaan Musyarakah dan peraturanperaturan lainnya yang terkait.

\section{Periode Pasca UU Nomor 25 Tahun 1992 tentang Perkoperasian}

Masa ini ditandai dengan lahirnya Undang-Undang Republik Indonesia Nomor 17 Tahun 2012 sebagai pengganti undang undang Nomor 25 Tahun 1992 Tentang Perkoperasian yang kemudian dibatalkan oleh Putusan Mahkamah Agung No.: 28/PUU-XI/2013, namun Undang- undang Perkoperasian yang baru tersebut, ternyata tidak secara jelas dan tegas memuat tentang norma hukum Koperasi Syariah. Pasal 87 ayat (3) dan (4) adalah satu-satunya pasal yang bisa dijadikan sebagai rujukan bagi keberadaan Koperasi Syariah. Pasal 87 ayat (3) berbunyi: "Koperasi dapat menjalankan usaha atas dasar prinsip ekonomi syariah, EISSN: 2540-8402 | ISSN: 2540-8399 dan ayat (4), berbunyi: “ Ketentuan mengenai Koperasi berdasarkan prinsip ekonomi syariah sebagaimana dimaksud pada ayat (3) diatur dengan Peraturan Pemerintah". Bunyi Pasal 87 ayat (3) dan (4) Undang-Undang Nomor 17 Tahun 2012 Tentang Perkoperasian tersebut, justeru semakin mempertegas bahwa kelembagaan Koperasi syariah di satu sisi diakui sebagai bagian dari kerangka sistem Koperasi Nasional, namun di sisi lain adanya keengganan dari pembuat Undang undang untuk secara tegas mengatur tentang kelembagaan ini (http://kementeriankoperasi.com/land asan-hukum-koperasi-syariah/).

Nilai-nilai islam yang diambil dari berbagai sudut pandang fikih justru terlihat dengan jelas dalam bentuk peraturan berupa fatwa dari Dewan Syariah Nasional MUI. Fatwa itu sendiri dalam sistem hukum di Indonesia klasifikasinya merupakan pendapat hukum (legal opinion) yang tidak termasuk dalam peraturan perundang-undangan, yang tidak mengikat dan memiliki daya paksa layaknya undang-undang, akan tetapi dalam perkembangannya beberapa fatwa yang dikeluarkan 
oleh Dewan Syariah Nasional Majelis Ulama Indonesia (DSNMUI) menurut Yeni Salma Barlinti dalam disertasinya merupakan hukum positif yang mengikat, sebab keberadaanya sering dilegitimasi lewat pertauran perundang-undangan oleh pemerintah, sehingga harus dipatuhi pelaku ekonomi syariah.(https://www.hukumonline.c om/berita/baca/lt4c675fd06e150/fat wa-dsn-merupakan-hukum-positifmengikat/).

\section{SIMPULAN}

Ajaran Islam kulutral mempunyai pengaruh yang sangat besar dalam memberi bentuk corak politik hukum Islam di Indonesia yang bersifat heterogen dan arah kebijakan politik hukum Islam di Indonesia dihubungkan dengan diberlakukannya Peraturan Perundang-undangan tentang Koperasi Syariah tidak terlihat begitu kental dalam Undang-Undang Koperasi, akan tetapi lebih banyak diterapkan dalam peraturan-peraturan yang lebih rendah dan sifatnya teknis, yakni peraturan menteri dan fatwa DSN-MUI.

\section{DAFTAR PUSTAKA}

Abu Ridha (2004), Islam dan Politik; Mungkinkah Bersatu?, Syamil Cipta Media, Bandung.

Amir Syarifuddin (2005), Meretas kebekuan Ijtihad, Isu-Isu Penting Hukum Islam Kontemporer di Indonesia, Ciputat Press, Tangerang.

Amrullah Ahmad SF dkk (1996),

Dimensi Hukum Islam Dalam Sistem Hukum Nasional, Gema Insani Press, Jakarta.

Hasan Alwi, et. All (2005), Kamus Besar Bahasa Indonesia, Balai Pustaka, Jakarta.

Huala Adolf (2006), Dasar-Dasar

Hukum Kontrak Internasional, Rafika Aditama, Bandung.

Idris Ramulyo (1997), Asas-asas

Hukum Islam. Sinar Grafika. Jakarta.

Ismail Muhammad Syah (1999), Filsafat Hukum Islam, Bumi Aksara, Jakarta. 
Moch. Mahfud MD (20010), Membangun Politik Hukum, Menegakkan Konstitusi,

Rajagrafindo Persada, Jakarta.

M. Khoirul Anam (20014), Islam,

Kekuasaan

Pemerintah,

Doktrin Iman dan Realitas

Sosial, Inisiasi Press.

Rusjdi Ali Muhammad (2003), Revitalisasi Syari'at Islam di

Aceh; Problem, Solusi dan

Implementasi, $\quad$ Menuju

Pelaksanaan Hukum Islam di

Nanggroe Aceh Darussalam,

Logos Wacana Ilmu, Ciputat.

Satjipto Rahardjo (2006), Ilmu

Hukum, Cetakan ke 6, Alumni,

Bandung.

Teungku Muhammad Hasbi Ash

Shiddieqy (2002), Islam dan

Politik Bernegara, PT. Pustaka

Rizki Putra, Semarang.

Abdullah Zawawi (2015), Politik

dalam Pandangan Islam, Jurnal

Ummul Qura, Vol. 5, No.1,

Maret
Mardani (2008), Hukum Islam dalam

Sistem Hukum Nasional,

Jurnal Hukum dan

Pembangunan,Ttahun ke 38, No. 2.

Usman (2017), Islam dan Politik, Telaah atas PemikiranPolitik Kontemporer di Indonesia, Jurnal Al-Daulah, Vol. 6 No. 1.

Yopi Marlina, Mala Yunisa Pratama (2017), Koperasi Syariah Sebagai Solusi penerapan Akad Syirkah Yang sah, Amwaluna: Jurnal Ekonomi dan Keuangan Syariah Vol. 1 No.2 .

https://www.hukumonline.com/berita /baca/1t4c675fd06e150/fatwadsn-merupakan-hukum-positifmengikat/

http://kementeriankoperasi.com/land asan-hukum-koperasi-syariah/ 